\title{
ANALISIS PENYUSUNAN DAN PUBLIKASI KARYA TULIS ILMIAH SEBAGAI TOLOK UKUR KOMPETENSI WIDYAISWARA
}

\author{
Riskha Nur Fitriyah ${ }^{1}$ \\ ${ }^{1}$ Balai Diklat Keagamaan Semarang \\ ${ }^{1}$ riskhafitriyah@gmail.com
}

\author{
https://doi.org/10.36052/andragogi.v9i2.232 \\ Diterima: 11 Oktober 2021 | Disetujui: 25 November 2021 | Dipublikasikan: 31 Desember 2021
}

\begin{abstract}
Abstrak
Penelitian ini bertujuan untuk mendeskripsikan kompetensi widyaiswara, menjelaskan faktor-faktor penghambat serta mengetahui upaya peningkatan kompetensi dan profesionalitas widyaiswara di BDK Semarang dalam menyusun dan mempublikasikan KTI (Karya Tulis Ilmiah). Metode yang digunakan dalam penelitian ini adalah metode kualitatif yang bersifat induktif. Teknik pengambilan sampel dilakukan secara purposive sampling, teknik pengumpulan data melalui wawancara dan telaah dokumen. Teknik analisis data dengan menggunakan model Miles and Huberman, meliputi: reduksi data, penyajian data dan penarikan kesimpulan. Dari hasil penelitian didapatkan bahwa widyaiswara BDK Semarang telah memahami dan kompeten dalam menyusun dan mempublikasikan karya tulis ilmiah. Faktor penghambat widyaiswara dalam menyusun KTI adalah: kurangnya motivasi, ide, referensi, waktu, sarana pendukung dan kesibukan mengajar. Sedangkan faktor penghambat widyaiswara dalam mempublikasikan $\mathrm{KTI}$, yaitu: kesulitan memenuhi gaya selingkung jurnal, waktu dan kurang informasi tentang cara publikasi. Upaya peningkatan kompetensi dan profesionalisme widyaiswara dalam menyusun dan mempublikasikan KTI yang sudah dilakukan oleh pihak manajemen adalah mengadakan Pelatihan KTI internal, mengirimkan widyaiswara untuk mengikuti kegiatan TOT (Training of trainer) KTI, TOT Kewidyaiswaraan Berjenjang Tingkat Menengah dan Tingkat Tinggi serta mengirimkan widyaiswara untuk mengikuti kegiatan "academic writing".
\end{abstract}

Kata Kunci: kompetensi, penyusunan, publikasi, karya tulis ilmiah

\begin{abstract}
This study aimed to describe the competence of widyaiswara, explain the inhibiting factors, and know the effort to increase the competence and professionalism of widyaiswara at Semarang Religious Training Center in composing and publishing the scientific paper. The method used in this study was an inductive qualitative method. The sampling technique by purposive sampling, data collection techniques are document review and interview. Data analysis techniques are using the Miles and Huberman model, including data reduction, data presentation, and conclusion. The results of the study showed that widyaiswara at Semarang Religious Training Center have understood and are competent in composing and publish of the scientific paper. The inhibiting factors for widyaiswara in composing and publishing the scientific paper, are difficulty fulfilling the writing style and journal form, time, and lack of information on how to publish. Efforts to increase the competence and professionalism of widyaiswara in composing and publishing the scientific paper have been done by the management is organize scientific writing training, send widyaiswara to follow the training of trainer the scientific paper, middle and high tier training and academic writing activities.
\end{abstract}

Keyword : competence, composing, publication and scientific paper

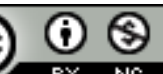

This work is licensed under a Creative Commons Attribution-NonCommercial 4.0 International License 


\section{PENDAHULUAN}

$P$ enyelenggaraan suatu pelatihan dapat dikatakan efektif dan berkualitas apabila semua komponen yang mendukung juga berkualitas, dimulai dari lembaga pelatihan, fasilitas, sarana dan prasarana, pengelola, kurikulum serta widyaiswaranya (Wuryastuti, 2019). Widyaiswara menjadi salah satu komponen yang sangat penting dalam pelatihan, karena harus mampu berperan secara maksimal dalam upaya meningkatkan kemampuan peserta pelatihan, baik sikap, pengetahuan dan keterampilannya. Sehingga diperlukan widyaiswara yang profesional sesuai dengan kompetensinya. Terdapat 4 standar kompetensi widyaiswara, antara lain: kompetensi pengelolaan pembelajaran, kompetensi kepribadian, kompetensi sosial dan substansi. (Lamazi, 2020).

Widyaiswara dituntut untuk dapat meningkatkan kompetensi dan pengembangan profesi melalui kegiatan seminar, workshop, pertemuan ilmiah, penerbitan buku, jurnal maupun kegiatan perkonsultasian (Suharsono, 2020). Permenpan RB Nomor 22 Tahun 2014 pasal 8 menjelaskan sub unsur dalam komponen pengembangan profesi seorang widyaiswara, antara lain: penyusunan karya tulis ilmiah (KTI) di bidang spesialisasi keahliannya dalam lingkup kediklatan, penemuan inovasi, penyusunan pedoman dan melakukan orasi ilmiah. Lebih lanjut dalam pasal 11 diatur hal besaran angka kredit yang dapat diperoleh widyaiswara dari sub unsur pengembangan profesi sebagai penentu kenaikan pangkat dan golongannya (Menpan RB, 2014).

Penyusunan KTI bagi widyaiswara juga dapat menjadi salah satu indikator penguasaan kompetensi substantif sekaligus menjadi media dan sarana komunikasi dalam menuangkan ide, pengetahuan dan keterampilannya dalam rangka melakukan pengembangan bahan ajar dan keberhasilan proses pembelajaran dalam pelatihan (LAN, 2008).

Berdasarkan hasil pengamatan, widyaiswara di BDK Semarang menyusun dan mempublikasikan KTI hanya sekedar untuk memenuhi angka kredit, belum untuk meningkatkan kompetensi dan profesionalitas. Data hasil pengamatan selama 2 tahun di 2019 dan 2020 menunjukkan bahwa dari jumlah widyaiswara sebanyak 35 orang, hanya 4 orang (11\%) yang menyusun dan mempublikasikan KTI, baik dalam bentuk buku, jurnal dan artikel majalah untuk meningkatkan kemampuan serta keterampilan dalam menulis. Sedangkan sebanyak 31 orang widyaiswara (89\%) menyusun dan mempublikasikan KTI sebagai persyaratan untuk memenuhi angka kredit.

Berdasarkan permasalahan di atas, maka penulis berkeinginan untuk mengetahui bagaimana kompetensi widyaiswara, apa saja yang menjadi faktor penghambat dan bagaimana upaya peningkatan kompetensi dan profesionalisme widyaiswara dalam menyusun dan mempublikasikan KTI. Penelitian ini bertujuan untuk mendeskripsikan kompetensi widyaiswara, menjelaskan faktorfaktor penghambat dan mengetahui upaya peningkatan kompetensi dan profesionalitas widyaiswara dalam menyusun dan mempublikasikan KTI.

Permenpan RB No. 38 Tahun 2017 menyebutkan bahwa standar kompetensi Aparatur Sipil Negara (ASN) adalah deskripsi pengetahuan, keterampilan dan perilaku dalam melaksanakan tugas, pokok, fungsi dan jabatannya. Terdapat 3 jenis kompetensi bagi ASN, antara lain: (1) kompetensi teknis merupakan pengetahuan, keterampilan, dan sikap/perilaku yang dapat diamati, diukur dan dikembangkan secara spesifik dan berkaitan langsung dengan bidang teknis jabatan; (2) kompetensi manajerial merupakan pengetahuan, keterampilan, dan sikap/perilaku yang dapat diamati, diukur, dikembangkan untuk memimpin dan/atau mengelola unit organisasi; dan (3) kompetensi sosial kultural 
merupakan pengetahuan, keterampilan, dan sikap/perilaku yang dapat diamati, diukur, dan dikembangkan terkait dengan pengalaman berinteraksi dengan masyarakat majemuk dalam hal agama, suku dan budaya, perilaku, wawasan kebangsaan, etika, nilai-nilai, moral, emosi dan prinsip yang wajib dipenuhi oleh setiap pemegang jabatan. Penyusunan dan publikasi KTI bagi widyaiswara termasuk dalah kompetensi teknis jabatan fungsional widyaiswara (Menpan RB, 2017).

Peningkatan kompetensi merupakan hal yang sangat penting bagi widyaiswara yang dapat dilakukan dengan kemampuan berinovasi sehingga dapat mengembangkan kapasitas diri, wawasan dan potensi diri seiring dengan era disruptif saat ini. Salah satu potensi diri yang dapat dikembangkan yaitu kemampuan meningkatkan kualitas karya tulis ilmiah bagi widyaiswara sebagai kewajiban dalam pengembangan profesi (Permana, 2019). Karya tulis ilmiah merupakan suatu ide/gagasan kreatif yang dituangkan secara tertulis, disusun dalam bentuk komprehensif berdasarkan data-data yang valid, dianalisis dengan teknik tertentu dengan sistematis dan diakhiri dengan kesimpulan. Karya tulis ilmiah ini memiliki karakteristik berupa isi, penyajian yang representatif dan bahasa lugas. Penyusunan KTI bersifat spesifik dengan kajian keilmuan secara mendalam dari penulisnya, dibutuhkan kompetensi atau kemampuan untuk mendeskripsikan hasil penelitian, pemikiran maupun ide kreatif dari sebuah kajian teoritis. KTI yang dihasilkan harus mempunyai sifat rasional, objektif, konsisten, dan bersifat ilmiah (Siahaan, $\mathrm{Pa}, \&$ Nababan, 2018).

Karya tulis ilmiah dalam lingkup kediklatan dan atau pelatihan merupakan karya ilmiah yang secara substantif bersinggungan dengan jenis, isi, dan komponen program pelatihan, serta sistem termasuk proses pelaksanan dan pembinaan serta unsur-unsur lain yang berhubungan dengan pelatihan. Sedangkan $\mathrm{KTI}$ yang terkait spesialisasi widyaiswara adalah karya ilmiah yang secara spesifik berhubungan dengan bidang keahlian maupuan kemampuan tertentu yang dimiliki widyaiswara sesuai dengan latar belakang pendidikan, rumpun keilmuan yang ditekuni dan dikuasai serta pengalaman kerjanya (LAN, 2008).

Penyusunan karya tulis ilmiah dapat menjadi tolok ukur kompetensi widyaiswara, yaitu kompetensi substantif. Dalam Peraturan Kepala Lembaga Administrasi Negara Nomor 5 Tahun 2008 tentang Standar Kompetensi Widyaiswara dijelaskan, bahwa kompetensi substantif merupakan kemampuan yang harus dimiliki oleh widyaiswara dalam bidang keilmuan dan keterampilan pada mata pelatihan yang diajarkan. Hal ini mencakup; a) penguasaan ilmu dan keterampilan yang sesuai dengan materi pelatihan. Indikator pencapaian subkompetensi ini dapat dirumuskan: (1) mampu mendeskripsikan substansi materi yang akan disampaikan, mengimplementasikan substansi materi yang akan disampaikan, (3) memberi respon berupa tanggapan/pertanyaan dari peserta pelatihan, 4) menganalisis substansi materi yang akan diberikan kepada peserta pelatihan. b) penyusunan karya tulis ilmiah yang terkait dengan lingkup kediklatan (pelatihan) dan/atau pengembangan spesialisasinya. Indikator pencapaian subkompetensi ini dapat dirumuskan: (1) menguasai sistematika penulisan, (2) menguasai metodologi penelitian, (3) menguasai teknik penulisan karya tulis ilmiah, dan (4) menganalisis hasil penelitian (LAN, 2008).

Karya tulis ilmiah widyaiswara dapat dipublikasikan dalam berbagai media publikasi. Secara umum, terdapat dua bentuk media publikasi yaitu bentuk buku dan non buku. KTI yang dipublikasikan dalam bentuk buku harus memenuhi persyaratan, antara lain: (1) diterbitkan oleh lembaga/organisasi profesi atau penerbit yang berbadan hukum dan diedarkan secara nasional, dan (2) memiliki ISBN (International Standard of Book Number). Sedangkan KTI yang dipublikasikan dalam 
bentuk non buku terdiri dari jurnal nasional baik yang belum terakreditasi maupun jurnal nasional yang terakreditasi, jurnal internasional, baik yang tidak bereputasi maupun yang bereputasi, majalah, prosiding, surat kabar dan website (Lamazi, 2020).

Adapun manfaat dari penelitian ini adalah: (1) menjadi salah satu cara dalam memotivasi widyaiswara agar dapat meningkatkan kualitas dalam penyusunan dan publikasi KTI; (2) menjadi pertimbangan dalam menyusun program dan kebijakan Pimpinan dalam meningkatkan kompetensi dan profesionalitas widyaiswara dalam hal penyusunan dan publikasi $\mathrm{KTl}$; dan (3) menemukan dan menganalisis faktor penghambat penyusunan KTI.

\section{METODE PENELITIAN}

Penelitian ini menggunakan pendekatan kualitatif yang bersifat induktif yang menggambarkan secara mendalam tentang penyusunan dan publikasi KTI sebagai salah satu kompetensi widyaiswara. Penelitian dilakukan di BDK Semarang, di Bulan Mei sampai Juni 2020. Kemampuan widyaiswara, faktor-faktor penghambat dan upaya peningkatan kompetensi widyaiswara dalam menyusun dan mempublikasikan KTI digali lebih mendalam.

Dalam penelitian kualitatif, yang menjadi instrumen utamanya adalah peneliti sendiri. Peneliti menggunakan peran sosial interaktif, melakukan observasi, wawancara, mencatat hasil pengamatan dan interaksi bersama responden (Lamazi, 2020). Instrumen yang digunakan dalam penelitian adalah peneliti, pedoman wawancara semi terstruktur dan dokumen.

Teknik pengumpulan data dilakukan dengan wawancara dan telaah dokumen. Sumber data diperoleh dari hasil wawancara dengan key informan. Key informan adalah orang yang dianggap mampu memberikan informasi tentang kompetensi widyaiswara dalam menyusun dan mempublikasikan KTI. Teknik untuk menentukan key informan dilakukan dengan purposive sampling, yaitu menentukan key informan didasarkan pertimbangan tertentu. Adapun yang menjadi key informan dalam penelitian ini berjumlah 4 orang, yaitu 2 widyaiswara yang banyak menyusun dan mempublikasikan KTI di berbagai media publikasi, 1 widyaiswara yang jarang menyusun dan mempublikasikan KTI serta 1 widyaiswara yang merupakan reviewer jurnal untuk mendapatkan data primer.

Telaah dokumen yang digunakan dalam penelitian ini dapat berupa arsip jurnal, baik cetak maupun non cetak serta data-data hasil publikasi KTI widyaiswara di berbagai media publikasi dalam kurun waktu 2017- 2020.

Teknik analisis data dengan menggunakan model Miles and Huberman, yang meliputi: reduksi data, penyajian data dan penarikan kesimpulan (Sugiyono, 2015). Analisis data dilakukan pada saat pengumpulan data berlangsung dan setelah selesai pengumpulan data. Pada saat wawancara peneliti sudah melakukan analisis terhadap jawawan informan. Analisis data dilakukan secara terus menerus sampai mendapatkan data jenuh. Data-data yang diperoleh dari hasil wawancara dan telaah dokumen dicatat secara teliti dan rinci. Data yang terkumpul dirangkum, untuk kemudian dipilih hal-hal pokok dan penting. Reduksi data dapat mempermudah peneliti untuk mengumpulkan data berikutnya dan memberikan gambaran lebih jelas. Setelah data direduksi, data disajikan baik dalam bentuk uraian deskriptif maupun tabel. Penyajian data dimaksudkan untuk mengorganisasikan dan menyusun pola hubungan tertentu sehingga topik penelitian akan semakin mudah dipahami. Langkah berikutnya yaitu penarikan kesimpulan dan verifikasi. Kesimpulan merupakan temuan terbaru yang sebelumnya belum pernah ada, dapat berupa deskripsi sebagai jawaban dari setiap rumusan masalah yang sedang diteliti. Keabsahan data dilakukan dengan triangulasi sumber, yaitu dengan 
membandingkan informasi-informasi yang didapatkan dari hasil wawancara dan telaah dokumen untuk menghindari subyektivitas peneliti.

\section{TEMUAN DAN PEMBAHASAN}

\section{Temuan}

Penelitian ini membahas tentang kompetensi widyaiswara, faktor penghambat serta analisis peningkatan kompetensi dan profesionalitas widyaiswara di BDK Semarang dalam penyusunan dan publikasi KTI. Data hasil wawancara dengan keempat informan, dapat dilihat pada tabel 1 , tabel 2 dan tabel 3 di bawah ini:

Tabel 1. Data Hasil Wawancara I

\begin{tabular}{|c|c|c|}
\hline \multirow{2}{*}{$\begin{array}{l}\text { Perta } \\
\text { nyaan }\end{array}$} & \multicolumn{2}{|c|}{ Informan } \\
\hline & 1 & 2 \\
\hline $\begin{array}{l}\text { Tujuan } \\
\text { menyusun } \\
\mathrm{KTI}\end{array}$ & $\begin{array}{l}\text { Syarat kenaikan } \\
\text { pangkat, } \\
\text { aktualisasi diri, } \\
\text { memperluas } \\
\text { wawasan, } \\
\text { mengembang } \\
\text { kan bahan ajar, } \\
\text { meneruskan } \\
\text { tradisi para } \\
\text { Ulama, } \\
\text { meningkatkan } \\
\text { kompetensi }\end{array}$ & $\begin{array}{l}\text { Karier, } \\
\text { mengasah } \\
\text { keterampilan } \\
\text { menulis, } \\
\text { menyebarkan } \\
\text { informasi, } \\
\text { menambah } \\
\text { wacana, } \\
\text { mewarisi ilmu } \\
\text { lewat tulisan, } \\
\text { menambah } \\
\text { percaya diri }\end{array}$ \\
\hline $\begin{array}{l}\text { Prosedur } \\
\text { menyusun } \\
\mathrm{KTI}\end{array}$ & $\begin{array}{l}\text { Menggali ide, } \\
\text { mencari } \\
\text { referensi } \\
\text { dituangkan } \\
\text { dalam tulisan, } \\
\text { dipublikasikan }\end{array}$ & $\begin{array}{l}\text { Mencari ide } \\
\text { kreatif, } \\
\text { dituangkan } \\
\text { dalam tulisan, } \\
\text { mencari } \\
\text { referensi dan } \\
\text { dipublikasikan }\end{array}$ \\
\hline $\begin{array}{l}\text { Faktor } \\
\text { pendu- } \\
\text { kung }\end{array}$ & $\begin{array}{l}\text { Motivasi yang } \\
\text { kuat dari dalam } \\
\text { diri, memenuhi } \\
\text { angka kredit, }\end{array}$ & $\begin{array}{l}\text { Motivasi yang } \\
\text { kuat dan ingin } \\
\text { naik pangkat } \\
\text { dan jabatan, }\end{array}$ \\
\hline $\begin{array}{l}\text { Hambatan } \\
\text { penyusu- } \\
\text { nan KTI }\end{array}$ & $\begin{array}{l}\text { Kesibukan } \\
\text { mengajar, } \\
\text { kesulitan } \\
\text { mencari } \\
\text { referensi, } \\
\text { terbatasnya ide }\end{array}$ & $\begin{array}{l}\text { Motivasi yang } \\
\text { berkurang saat } \\
\text { menulis, dalam } \\
\text { menyusun buku } \\
\text { butuh waktu } \\
\text { lama }\end{array}$ \\
\hline
\end{tabular}

\begin{tabular}{|c|c|c|}
\hline \multirow{2}{*}{$\begin{array}{l}\text { Perta } \\
\text { nyaan }\end{array}$} & \multicolumn{2}{|c|}{ Informan } \\
\hline & 1 & 2 \\
\hline $\begin{array}{l}\text { Media } \\
\text { Publikasi } \\
\text { KTI }\end{array}$ & $\begin{array}{l}\text { Jurnal, majalah, } \\
\text { website }\end{array}$ & $\begin{array}{l}\text { Buku, jurnal, } \\
\text { media massa }\end{array}$ \\
\hline $\begin{array}{l}\text { Prosedur } \\
\text { proses } \\
\text { publikasi }\end{array}$ & $\begin{array}{l}\text { Naskah dikirim, } \\
\text { proses review, } \\
\text { revisi dan } \\
\text { publish }\end{array}$ & $\begin{array}{l}\text { Naskah dikirim, } \\
\text { proses review, } \\
\text { revisi dan } \\
\text { publish }\end{array}$ \\
\hline $\begin{array}{l}\text { Kendala } \\
\text { saat } \\
\text { mempubli } \\
\text {-kasikan } \\
\text { KTI }\end{array}$ & $\begin{array}{l}\text { Rentang waktu } \\
\text { yg cukup lama } \\
\text { dari mengirim } \\
\text { naskah sampai } \\
\text { di- publish } \\
\text { (jurnal) }\end{array}$ & $\begin{array}{l}\text { Masih } \\
\text { rendahnya } \\
\text { penghargaan } \\
\text { terutama dari } \\
\text { segi finansial }\end{array}$ \\
\hline
\end{tabular}

Sumber: Data di olah Tahun 2021

Data dari Tabel 1. dapat ditemukan bahwa kedua informan mempunyai tujuan, motivasi dalam menyusun dan mempublikasikan KTI. Informan juga mengetahui tentang prosedur, faktor pendukung, faktor penghambat dalam menyusun dan mempublikasikan KTI. Lebih lanjut, kedua informan telah mempublikasikan KTI yang telah disusun dalam berbagai media publikasi, yaitu jurnal, majalah, website, buku dan media massa.

Hasil wawancara dengan informan yang ketiga dapat lihat pada tabel 2. berikut ini :

Tabel 2. Data Hasil Wawancara II

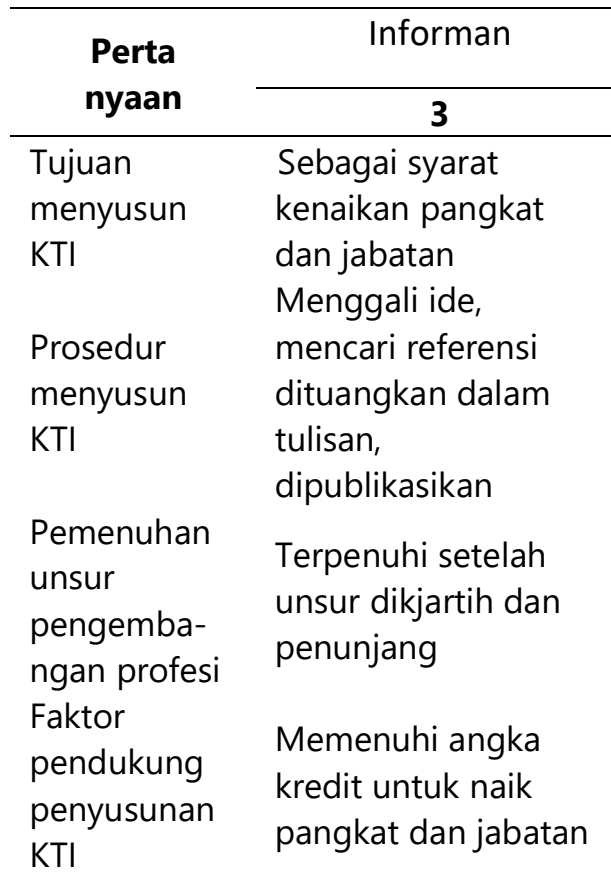




\begin{tabular}{|c|c|}
\hline \multirow{2}{*}{$\begin{array}{l}\text { Perta } \\
\text { nyaan }\end{array}$} & Informan \\
\hline & 3 \\
\hline $\begin{array}{l}\text { Hambatan } \\
\text { penyusu- } \\
\text { nan KTI }\end{array}$ & $\begin{array}{l}\text { Membutuhkan waktu } \\
\text { dan konsentrasi yang } \\
\text { lebih, terbatasnya ide } \\
\text { dan motivasi }\end{array}$ \\
\hline $\begin{array}{l}\text { Media } \\
\text { Publikasi KTI }\end{array}$ & Jurnal \\
\hline $\begin{array}{l}\text { Prosedur } \\
\text { proses } \\
\text { publikasi }\end{array}$ & $\begin{array}{l}\text { Naskah dikirim, di- } \\
\text { review, revisi dan } \\
\text { publish }\end{array}$ \\
\hline $\begin{array}{l}\text { Kendala saat } \\
\text { mempublikas } \\
\text { ikan KTI }\end{array}$ & $\begin{array}{l}\text { Waktu yg lama, } \\
\text { kurang informasi } \\
\text { tentang cara } \\
\text { publikasi dan } \\
\text { kesulitan memenuhi } \\
\text { gaya selingkung } \\
\text { jurnal }\end{array}$ \\
\hline
\end{tabular}

Sumber: Dara di olah Tahun 2021

Hasil wawancara dalam tabel. 2 didapatkan bahwa informan menyusun dan mempublikasikan KTI hanya untuk memenuhi angka kredit untuk kenaikan pangkat. Informan mempublikasikan KTI dalam bentuk jurnal.

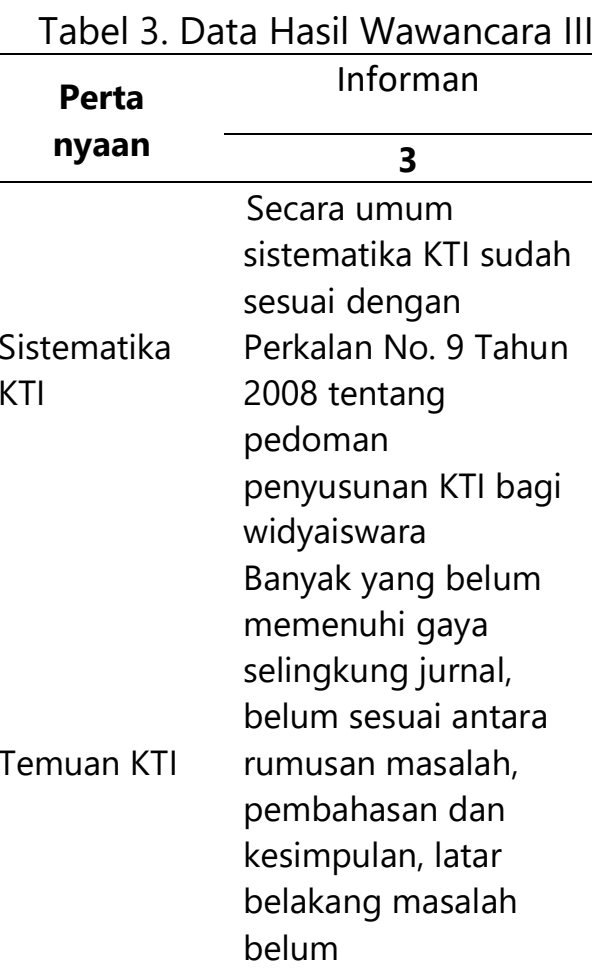

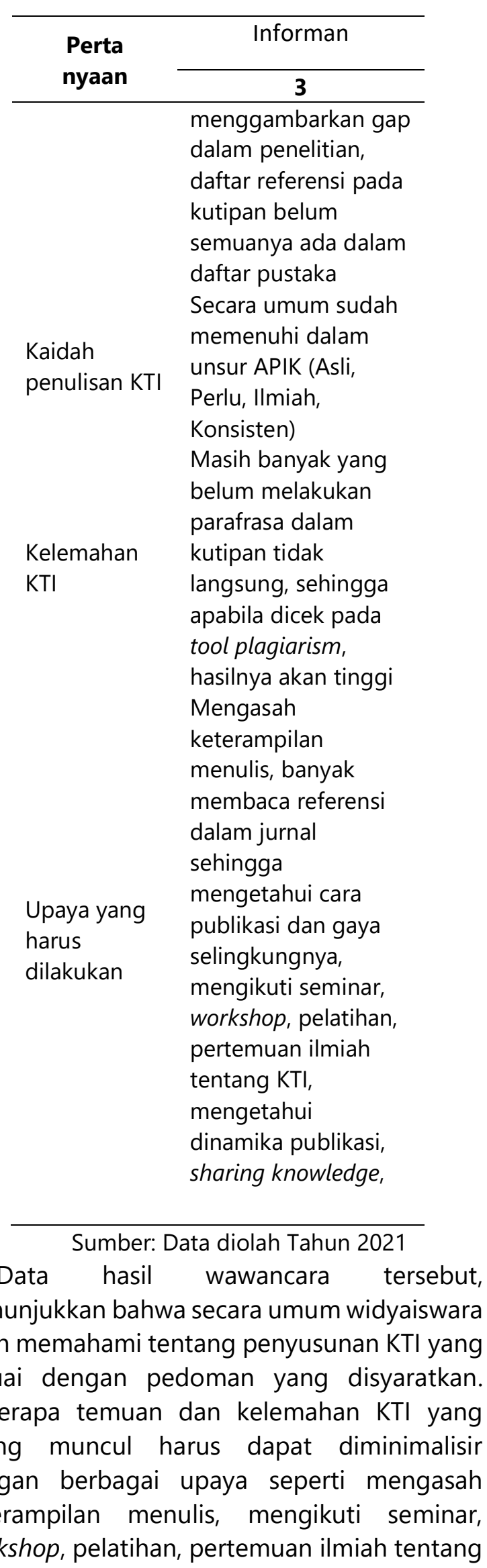


$\mathrm{KTI}$, mengetahui dinamika publikasi, melakukan sharing knowledge.

Teknik pengumpulan data berikutnya adalah dengan telaah dokumen. Adapun data hasil telaah dokumen disajikan dalam tabel 1. tabel 2. dan gambar 1. di bawah ini:

Tabel 4. Publikasi KTI WI BDK Semarang Dalam Jurnal (2018 - 2020)

\begin{tabular}{clc}
\hline No. & Media Publikasi & $\begin{array}{c}\text { Jumlah } \\
\text { Widyaiswara }\end{array}$ \\
\hline 1. & Buku & 10 \\
2. & Artikel majalah & 29 \\
3. & Prosiding seminar & 11 \\
4. & Website & 9 \\
5. & Media massa & 7 \\
6. & Jurnal nasional & 27 \\
7. & Jurnal nasional & terakreditasi \\
8. & Jurnal Internasional & 11 \\
& $\begin{array}{l}\text { Tidak bereputasi } \\
\text { 9. Jurnal Internasional }\end{array}$ & 3 \\
\hline
\end{tabular}

Sumber: BDK Semarang di olah Tahun 2020

Data tersebut menyebutkan berbagai media publikasi KTI widyaiswara, antara lain: berupa buku, artikel majalah, prosiding seminar, website, media massa, jurnal nasional, baik yang belum terakreditasi maupun terakreditasi dan jurnal internasional, baik yang tidak bereputasi maupun bereputasi terindeks scopus.

Sedangkan untuk data sebaran pangkat dan jabatan widyaiswara dapat dilihat pada tabel 2. Berikut ini:

Tabel 4. Sebaran Pangkat Dan Jabatan Widyaiswara BDK Semarang

\begin{tabular}{llcc}
\hline No & \multicolumn{1}{c}{ Pangkat } & \multicolumn{1}{c}{ Jabatan } & Jumlah \\
\hline 1. & $\begin{array}{l}\text { Pembina Utama - } \\
\text { IV/e }\end{array}$ & $\begin{array}{l}\text { Widyaiswara } \\
\text { Ahli Utama }\end{array}$ & 4 \\
2. & $\begin{array}{l}\text { Pembina Utama } \\
\text { Madya - IV/d }\end{array}$ & $\begin{array}{l}\text { Widyaiswara } \\
\text { Ahli Utama }\end{array}$ & 5 \\
3. & $\begin{array}{l}\text { Pembina Utama } \\
\text { Muda - IV/c }\end{array}$ & $\begin{array}{l}\text { Widyaiswara } \\
\text { Ahli Madya }\end{array}$ & 12 \\
\hline
\end{tabular}

\begin{tabular}{|c|c|c|c|}
\hline No & Pangkat & Jabatan & Jumlah \\
\hline 4. & $\begin{array}{l}\text { Pembina Tk. I - } \\
\text { IV/b }\end{array}$ & $\begin{array}{l}\text { Widyaiswara } \\
\text { Ahli Madya }\end{array}$ & 5 \\
\hline 5. & Pembina - IV/a & $\begin{array}{l}\text { Widyaiswara } \\
\text { Ahli Madya }\end{array}$ & 5 \\
\hline 6. & Pembina - IV/a & $\begin{array}{l}\text { Widyaiswara } \\
\text { Ahli Muda }\end{array}$ & 1 \\
\hline 7. & $\begin{array}{l}\text { Penata Tk. I - } \\
\text { III/d }\end{array}$ & $\begin{array}{l}\text { Widyaiswara } \\
\text { Ahli Muda }\end{array}$ & 1 \\
\hline 8. & Penata - III/C & $\begin{array}{l}\text { Widyaiswara } \\
\text { Ahli Madya }\end{array}$ & 2 \\
\hline
\end{tabular}

Sumber: Data Kepegawaian BDK Semarang Per 1 Januari 2021

Data tersebut menunjukkan bahwa secara umum widyaiswara di BDK Semarang dapat naik pangkat dan jabatan setelah memenuhi angka kredit yang dipersyaratkan, walaupun ada beberapa yang terhambat kenaikan pangkat dan jabatannya. Sebanyak 9 orang dengan jabatan widyaiswara ahli utama, 24 orang dengan jabatan widyaiswara ahli madya dan 2 orang dengan jabatan widyaiswara ahli muda.

Prosentase kenaikan pangkat disajikan dalam gambar 1. Berikut ini :

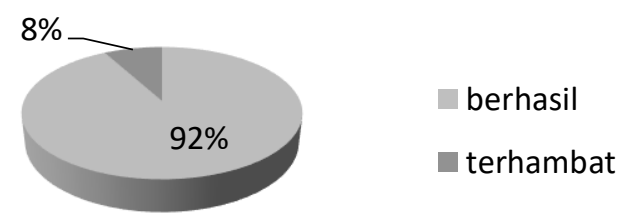

Gambar 1. Prosentase kenaikan pangkat dan jabatan

Gambar tersebut menjelaskan bahwa sebesar $92 \%$ widyaiswara sudah berhasil naik pangkat dan jabatan karena sudah terpenuhi dalam sub unsur pengembangan profesi dan sebesar $8 \%$ widyaiswara terhambat kenaikan pangkat dan jabatannya karena belum memenuhi sub unsur pengembangan profesi.

\section{Pembahasan}

Berdasarkan data hasil wawancara dan telaah dokumen dapat dianalisis bahwa widyaiswara BDK Semarang telah memahami, 
memiliki kemampuan dan keterampilan dalam menyusun dan mempublikasikan karya tulis ilmiah. Tujuan utama widyaiswara menyusun dan mempublikasikan KTI adalah sebagai sarana pengembangan karier karena menjadi salah satu syarat pemenuhan angka kredit untuk naik pangkat dan jabatan, pada unsur pengembangan profesi sesuai yang dipersyaratkan dalam Permenpan RB Nomor 22 Tahun 2014 tentang jabatan fungsional widyaiswara dan angka kreditnya.

Tujuan yang lain diantaranya: sebagai sarana aktualisasi diri, memperluas wawasan, mengembangkan bahan ajar, menyebarkan informasi, meningkatkan kompetensi, menambah wacana, mewarisi ilmu lewat tulisan serta menambah percaya diri. Hal ini sesuai dengan hasil penelitian Pardjono et al. (2017) yang menunjukkan bahwa KTI yang berhasil dipublikasikan merupakan sebuah aktualisasi diri dari penulis dan sebagai pengakuan ideide. Selain itu, publikasi ilmiah menjadi trigger yang berfungsi menarik minat orang lain di daerah penelitian lainnya serta untuk memperkaya topik penelitian. Lebih lanjut dalam LAN (2008) menyebutkan bahwa penyusunan dan publikasi KTI juga menjadi salah satu indikator penguasaan kompetensi profesional widyaiswara. Ide dan pengetahuan yang dimilki dituangkan dalam sebuah tulisan untuk mengembangkan bahan ajar. Pengembangan profesi melalui penyusunan dan publikasi KTI juga mampu mendorong widyaiswara untuk memperkaya wawasan dan memperdalam penguasaan bidang studi yang ditekuni dalam memantapkan spesialisasinya. Prayitno (2017) menambahkan bahwa hadirnya karya tulis ilmiah yang telah dipublikasikan dapat memperkaya dan menyebarluaskan ilmu pengetahuan, sebagai media komunikasi, membangkitkan rasa percaya diri dan mampu menghasilkan produk atau karya inovasi tertentu.

Widyaiswara mempublikasikan KTI yang telah selesai disusun ke dalam berbagai media publikasi antara lain: buku, artikel majalah, prosiding seminar, website, media massa, jurnal nasional, baik yang belum terakreditasi maupun terakreditasi dan jurnal internasional, baik yang tidak bereputasi maupun bereputasi terindeks scopus. Hal ini sesuai dengan LAN (2015) tentang pedoman penilaian angka kredit jabatan fungsional widyaiswara yang menyebutkan bahwa hasil akhir penyusunan karya tulis ilmiah dapat berbentuk buku, non buku dan makalah. Yang termasuk non buku yaitu artikel yang dimuat dalam jurnal ilmiah, majalah ilmiah dan kumpulan prosiding. Makalah yang dimaksud adalah makalah yang dipaparkan widyaiswara sebagai pemakalah atau narasumber dalam forum pertemuan ilmiah, seperti lokakarya, simposium, konferensi dan seminar baik ditingkat internasional, nasional maupun instansi.

Prosedur dalam menyusun KTI dimulai dari penggalian ide yang dituangkan dalam tulisan, mencari referensi dan publikasi. Hal ini sesuai dengan hasil penelitian Prayitno (2017) yang menyatakan bahwa karya tulis ilmiah disusun dengan terlebih dahulu melakukan kegiatan ilmiah secara sistematis, dimulai dengan mengamati, mengidentifikasi, menganalisis, mengkaji hasil kegiatan dengan teori yang relevan, dan kesimpulan. Dalam menyusun sebuah KTI diperlukan 2 point penting yaitu dimulai dari adanya sebuah ide dan dilakukan pengkajian secara empiris dengan literatur serta teori yang relevan. Literatur dapat berupa referensi dari jurnal, baik jurnal nasional maupun jurnal internasional.

Dari uraian tersebut dapat dikatakan bahwa widyaiswara BDK Semarang telah memahami dan kompeten dalam menyusun dan mempublikasikan karya tulis ilmiah. Hal tersebut juga diperkuat dari data hasil telaah dokumen bahwa sebesar 92\% atau 32 widyaiswara sudah berhasil naik pangkat dan jabatan karena sudah terpenuhi dalam sub unsur pengembangan profesi, sedangkan sisanya $8 \%$ atau 3 widyaiswara terhambat kenaikan pangkat dan jabatannya karena belum memenuhi sub unsur pengembangan 
profesi. Dikatakan terhambat kenaikan pangkat dan jabatannya, apabila dalam kurun waktu 3 tahun atau lebih belum dapat naik pangkat atau jabatan karena belum terpenuhinya jumlah angka kredit yang dipersyaratkan terutama di unsur $C$, yaitu pengembangan profesi. Solusi atas permasalahan ini adalah dengan melakukan kegiatan konsultasi terhadap senior atau melakukan kegiatan tutor sebaya kepada sesama teman sejawat.

Kompetensi dalam menyusun dan mempublikasikan KTI harus terus ditingkatkan, sehingga tidak hanya sebagai pemenuhan angka kredit pada unsur pengembangan profesi saja akan tetapi untuk mengembangkan potensi, mengasah skill/keterampilan dan meningkatkan kompetensi serta profesionalitas. Sesuai dengan pendapat Wirda (2021) yang menyatakan bahwa pengembangan profesionalisme widyaiswara melalui penyusunan dan publikasi KTI bukan hanya dilihat dari jumlahnya saja, namun dari segi kualitas juga menjadi patokan utama dalam rangka pemenuhan karya tulis ilmiah tersebut.

Motivasi menjadi salah satu faktor pendukung widyaiswara BDK Semarang dalam menyusun dan mempublikasikan KTI. Faktor pendukung yang lainnya, yaitu meneruskan tradisi para Ulama, meningkatkan kompetensi, Mewarisi ilmu lewat tulisan, menambah percaya diri. Kebutuhan untuk pengembangan profesi dan peningkatan ke jenjang kepangkatan yang lebih tinggi dapat menjadi motivasi yang cukup kuat bagi seorang Widyaiswara untuk melakukan penelitian. Selanjutnya Asnofidal (2019) menambahkan bahwa penyusunan karya tulis ilmiah memerlukan motivasi yang tinggi, karena menguras konsentrasi, pikiran dan waktu. Terdapat 2 jenis motivasi yang mempengaruhi, yaitu motivasi intrinsik dan motivasi ekstrinsik. Motivasi intrinsik berasal dari dalam diri, sedangkan motivasi ekstrinsik muncul karena faktor dari luar seperti lingkungan pekerjaan dan karier.
Beberapa faktor penghambat yang sering dihadapi widyaiswara dalam menyusun KTI meliputi terbatasnya ide, motivasi, waktu penyusunan yang cukup lama, kesibukan mengajar dan kesulitan mencari referensi. Pardjono et al (2017) menambahkan bahwa dari hasil penelitiannya terkait faktor penghambat penyusunan $\mathrm{KTI}$, yaitu kesibukan kerja, lingkungan kerja dan fasilitas yang kurang memadai. Sedangkan yang menjadi kendala dalam mempublikasikan KTI adalah besarnya biaya, ketersediaan langganan jurnal dan kurangnya akses jurnal sebagai referensi.

Adapun dari data yang dihimpun, faktor penghambat widyaiswara dalam mempublikasikan KTI yaitu rentang waktu publikasi yang cukup lama dari proses submit sampai artikel diterima di sebuah jurnal, kurang informasi tentang cara publikasi dan kesulitan memenuhi gaya selingkung jurnal dan masih rendahnya penghargaan terutama dari segi finansial. Lamazi (2020) mengemukakan bahwa KTI yang akan dimuat dalam sebuah jurnal harus mengikuti aturan penulisan atau familiar disebut dengan gaya selingkung. Hal ini menjadi salah satu kendala yang dihadapi dalam proses publikasi.

Berbagai upaya juga telah dilakukan oleh pihak manajemen untuk terus memotivasi, meningkatkan kuantitas dan kualitas KTI widyaiswara agar dapat mempublikasikannya dalam jurnal nasional terakreditasi dan jurnal internasional bereputasi. Senada dengan pendapat Permana (2019) salah satu contoh kualitas KTI yang dihasilkan widyaiswara adalah dapat dipublikasikan dalam jurnal terakreditasi maupun jurnal internasional yang bereputasi. Penyelenggaraan Pelatihan Di Wilayah Kerja Karya Tulis IImiah internal di BDK Semarang yang sudah dilaksanakan selama 2 tahun berturut-turut yaitu di awal tahun 2020 dan 2021 merupakan salah satu upaya yang dilakukan. Pengiriman widyaiswara dalam kegiatan "academic writing" juga salah satu upaya yang efektif karena dari kegiatan ini sudah membuahkan hasil, yaitu 1 artikel 
mampu publish di jurnal internasional terindeks Scopus di tahun 2020. Pemberian motivasi dan kesempatan untuk melanjutkan studi ke jenjang pendidikan yang lebih tinggi yaitu Program Doktoral (S3) juga efektif dalam meningkatkan kualitas penyusunan dan publikasi KTI dalam jurnal internasional bereputasi.

Pengiriman widyaiswara untuk mengikuti kegiatan TOT (Training of Trainer) KTI baik secara luring maupun daring yang diselenggarakan oleh Pusdiklat Tenaga Teknis Pendidikan dan Keagamaan Kementerian Agama sudah dilakukan setiap tahunnya. Dalam 3 tahun berturut-turut yaitu 2018-2020, beberapa widyaiswara juga ditugaskan untuk mengikuti Pelatihan penjenjangan, yaitu TOT Kewidyaiswaraan Tingkat Menengah dan TOT Kewidyaiswaraan Tingkat Utama yang diselenggarakan oleh LAN RI. TOT Kewidyaiswaraan Menengah diperuntukan bagi widyaiswara ahli muda yang akan menduduki jabatan widyaiswara ahli madya dengan output pelatihan $\mathrm{KTI}$ hasil penelitian yang telah diseminarkan. Sedangkan TOT Kewidyaiswaraan Tingkat Utama diperuntukkan bagi widyaiswara ahli madya (IV/a, IV/b dan IV/c) yang akan menduduki jabatan widyaiswara ahli utama (IV/d) dengan output KTI hasil perkonsultasian yang telah diseminarkan.

Fasilitas koneksi internet yang memadai dengan kemudahan akses internet untuk mencari referensi jurnal online juga terus ditingkatkan dengan menambah kapasitas bandwith. Saat ini referensi mengenai penelitian dan publikasi ilmiah didapat secara online di google scholar. Hasil karya tulis ilmiah widyaiswara dapat dilihat dari akun google scholar yang dimiliki. Sebanyak 14 widyaiswara (40\%) telah memiliki akun google scholar. Salah satu manfaat dari kepemilikan akun google scholar adalah sebagai sarana publikasi hasil penyusunan KTI sehingga dapat meningkatkan kualitas sebuah artikel (Arianto, 2020).

\section{PENUTUP}

\section{Simpulan}

Widyaiswara BDK Semarang telah memahami dan kompeten dalam menyusun dan mempublikasikan karya tulis ilmiah. Faktor penghambat widyaiswara dalam menyusun KTI adalah: terbatasnya motivasi, ide, referensi, waktu, sarana pendukung dan kesibukan mengajar. Sedangkan faktor penghambat widyaiswara dalam mempublikasikan $\mathrm{KTI}$, yaitu: kesulitan memenuhi gaya selingkung jurnal, waktu dan kurang informasi tentang cara publikasi. Upaya peningkatan kompetensi dan profesionalisme widyaiswara dalam menyusun dan mempublikasikan KTI yang sudah dilakukan oleh pihak manajemen adalah mengadakan Pelatihan KTI internal, mengirimkan widyaiswara untuk mengikuti kegiatan TOT KTI, TOT Kewidyaiswaraa Berjenjang Tingkat Menengah dan Tingkat Tinggi serta mengirimkan widyaiswara untuk mengikuti kegiatan "academic writing".

\section{Rekomendasi}

Beberapa rekomendasi dari temuan penelitian yang telah dibahas, antara lain :

a. Pihak manajemen (pimpinan) BDK Semarang perlu memfasilitasi adanya pertemuan atau diskusi ilmiah tentang pembuatan akun google scholar dan sinta maupun membuat bengkel karya tulis ilmiah.

b. Melakukan kerjasama dengan pihak terkait tentang submission naskah, penulisan artikel jurnal nasional terakreditasi maupun jurnal internasional bereputasi.

c. Perlu dilakukan penelitian lebih lanjut untuk menganalisis kualitas KTI yang sudah dipublikasikan dalam jurnal nasional terakreditasi dan jurnal internasional bereputasi. 


\section{DAFTAR PUSTAKA}

Arianto, I. dan S. (2020). Pelatihan Registrasi Google Scholar dan Sinta pada. 5(3), 775-782.

Asnofidal. (2019). Motivasi Widyaiswara Dalam Penulisan Karya Tulis Ilmiah Pada Badan Pengembangan Sumber Daya Manusia Provinsi Jambi. 3(2016), 167-175.

Lamazi. (2020). Analisis Kemampuan Widyaiswara dalam Membuat karya Tulis Ilmiah di PBSDMD Provinsi Sumatera Selatan. Jurnal Ekonomi \& Ekonomi Syariah, 3(1), 174-188.

LAN. (2008). Peraturan Kepala LAN Nomor 9 Tahun 2008 Tentang Pedoman Penyusunan Karya Tulis Ilmiah Bagi Widyaiswara. Jakarta.

LAN. (2008). Perkalan No. 5 Tahun 2008 Tentang Standar Kompetensi Widyaiswara (pp. 1-10). pp. 1-10. Jakarta.

LAN. (2015). Perkalan No. 26 Tahun 2015 tentang Pedoman Penilaian Angka Kredit Jabatan Fungsional Widyaiswara.

Menpan RB. (2014). Permenpan RB No. 22 Tahun 2014 Tentang Jabatan Fungsional Widyaiswara dan Angka Kreditnya. Jakarta.

Menpan RB. (2017). Peraturan Menteri Pendayagunaan Aparatur Negara dan Reformasi Birokrasi Nomor 38 Tahun 2017 Tentang Standar Kompetensi Jabatan Aparatur Sipil Negara. Jakarta: Sekretariat Negara, p. 108. Jakarta.

Pardjono, P., Nuchron, N., Surono, S., \& Ramdani, S. D. (2017). Analisis Faktor-Faktor Penghambat Produktivitas Publikasi Karya Ilmiah Mahasiswa PPs UNY pada Jurnal Internasional Terindeks. Jurnal Dinamika Vokasional Teknik Mesin, 2(2), 139. https://doi.org/10.21831/dinamika.v2i2.16002

Permana, R. (2019). Optimalisasi Profesionalisme Widyaiswara Melalui Peningkatan Kualitas Karya Tulis Ilmiah. Jurnal Teruna Bhakti, 1(2), 128-136. Retrieved from http://stakterunabhakti.ac.id/ejournal/index.php/teruna/article/view/20/20\%0Ahttp://stakterunabhakti.a c.id/e-journal/index.php/teruna

Prayitno, T. A. (2017). Kiat Menulis Dan Publikasi Karya Tulis Ilmiah. 1-9.

Siahaan, P. G. S., Pa, R. B. B., \& Nababan, R. (2018). Kompetensi Penulisan Karya Ilmiah Dalam Meningkatkan Kualitas Kegiatan IImiah Mahasiswa Jurusan PPKn Fakultas IImu Sosial UNIMED Tahun 2017. Seminar Nasional Tahunan Fakultas Ilmu Sosial Universitas Negeri Medan, 2, 2549-435. Retrieved from http://semnasfis.unimed.ac

Sugiyono. (2015). Metode Penelitian Manajemen. Bandung: Alfabeta.

Suharsono, A. (2020). Konsep Peningkatan Kompetensi Widyaiswara dalam Penyusunan Karya Tulis Ilmiah Indonesia dengan Model Pembelajaran 70-20-10. Jurnal Kewidyaiswaraan, 5(1), 11-20. Retrieved from http://jurnalpjf.lan.go.id/index.php/jurnalkewidyaiswaraan/article/view/49

Wirda, W. (2021). Urgensi Pelatihan KTI untuk Meningkatkan Kompetensi Widyaiswara dalam Penulisan Karya IImiah. J-MAS (Jurnal Manajemen Dan Sains), 6(1), 53. https://doi.org/10.33087/jmas.v6i1.227

Wuryastuti, N. S. (2019). Implementasi Kompetensi Widyaiswara Dalam Pengelolaan Pembelajaran Pada Diklat Kepemimpinan Tingkat IV Universitas Pendidikan Indonesia | repository.upi.edu | perpustakaan.upi.edu. Bandung. 